\title{
Prevalence, risk factors and underdiagnosis of asthma in the general population aged over 60 years
}

\author{
Izabela Kuprys-Lipinska ${ }^{1}$, Jerzy Liebhart², Cezary Palczynski ${ }^{1}$, Piotr Lacwik ${ }^{1}$, Mateusz Jonakowski ${ }^{1}$, Piotr Kuna ${ }^{1}$
}

${ }^{1}$ Department of Internal Medicine, Asthma and Allergy, Norbert Barlicki Memorial University Hospital No. 1, Medical University of Lodz, Lodz, Poland

${ }^{2}$ Department of Internal Medicine and Allergology, Wroclaw Medical University, Wroclaw, Poland

Adv Dermatol Allergol 2019; XXXVI (1): 86-91

DOI: https://doi.org/10.5114/ada.2018.73330

\begin{abstract}
Introduction: Bronchial asthma is one of the frequent chronic diseases in elderly persons. Global data show that $6.5-17 \%$ of the elderly suffer from asthma. However, there are no Polish data available on asthma prevalence in this group.

Aim: This article is a retrospective analysis of the Polish Multicentre Study of Epidemiology of Allergic Diseases (PMSEAD) results aimed at assessing prevalence and clinical characteristics in the elderly.

Material and methods: The study was conducted in 1998-1999 in 11 research centres in Poland, including the Lodz centre. The study included randomly selected subjects of both sexes. Demographics and prevalence were assessed among adults (aged 16-80 years) based on the nationwide database and the detailed clinical analysis was based on the Lodz centre database.

Results: Nationwide data were obtained from 12970 adults, including 1057 respondents in the Lodz Province; 20.3\% of respondents in Poland and $23.6 \%$ in the Lodz Province were over 60 years of age. In both groups, elderly participants significantly more frequently suffered from asthma (asthma prevalence in this group was $6.7 \%$ for Poland and $12.0 \%$ for the Lodz Province). The multivariate analysis demonstrated that age over 60 years $(\mathrm{OR}=2.08)$, residence in the city centre $(O R=3.30)$, and occurrence of seasonal allergic rhinitis $(O R=3.11)$ were significant risk factors for asthma occurrence among the residents of the Lodz Province. Among the elderly in Lodz, almost $50 \%$ of patients with asthma had not had a proper diagnosis made despite reporting clinical symptoms.

Conclusions: In Poland asthma is a common and frequently underdiagnosed disease in the elderly.
\end{abstract}

Key words: asthma prevalence, elderly, underdiagnosis.

\section{Introduction}

The WHO warns that "the world is rapidly aging". With the prolonged lifespan, a steady increase in the percentage of elderly people is observed in the general population. There are currently 900 million people in the world aged 60 years and older, and by 2050 this population is expected to grow to 2 billion [1]. In Poland, residents over the age of 60 represent $22.6 \%$ of the total population [2]; thus, according to Rosset's scale we are a demographically old society [3]. This raises specific problems for the healthcare system because the group of the elderly is special as it is characterized by a different form of morbidity, in particular comorbidity and associated polypragmasy, more frequent iatrogenic reactions, as well as different course of diseases and prognosis
[4]. The characteristics of the elderly and recognition of their needs in this area are important elements of public health planning.

Bronchial asthma is one of the frequent chronic diseases that occur in the elderly. It usually appears in early childhood (early onset asthma) and lasts for the rest of life, but the first symptoms may also develop at an old age (late onset asthma). Global data show that $6.5 \%$ to $17 \%$ [5] of elderly persons suffer from asthma. In Poland, according to epidemiological data, 5.4\% [6] - 9.4\% [7] of adults develop asthma. However, there are no data available on the prevalence of this disease in the elderly.

Of Polish epidemiological studies, only the Polish Multicentre Study of Epidemiology of Allergic Diseases (PMSEAD) has surveyed elderly people.

Address for correspondence: Izabela Kuprys-Lipinska MD, PhD, Department of Internal Medicine, Asthma and Allergy, Norbert Barlicki Memorial University Hospital No. 1, Medical University of Lodz, 22 Kopcinskiego St, 90-153 Lodz, Poland, phone: +48 606819702, fax: +48 426781176 , e-mail: ikuprys@wp.pl Received: 1.12.2017, accepted: 20.12.2017. 


\section{Aim}

The present article is a retrospective analysis of data from a nationwide study conducted in order to assess the asthma prevalence as well as demographic and clinical characteristics of this group of patients.

\section{Material and methods}

The study was carried out in the years 1998-1999 in 11 regional research centres of Poland including the Lodz centre. The study population comprised individuals of both sexes aged 3 to 80 years who were randomly selected by the Provincial Statistical Offices according to place of residence. The detailed study and randomization protocol has been published before [6]. However, it is worth mentioning that randomization was performed in each region in three representative areas with a different level of air pollution. The study was based on a survey, using uniform research questionnaires, which were completed at the homes of selected subjects. Additionally, in some centres, resting spirometry and skin prick tests were performed (the description of the methods used had been published earlier [8]). Diagnoses were established by an expert appointed in each region on the basis of the collected data and additional tests which, if required, were performed in a particular centre.

The research concerning a demographic analysis of the elderly population and prevalence was conducted in accordance with the data of the adult people (aged $>16$ years and $\leq 80$ years) collected in all centres. A detailed clinical analysis was carried out on the database of the Lodz centre.

\section{Statistical analysis}

Data were presented as prevalence and odds ratios (OR) with corresponding 95\% confidence intervals (CI). Analysis of quantitative data was performed by the analysis of variance (ANOVA) and analysis of qualitative data by nonparametric tests: $\chi^{2}$ and the exact Fisher's tests. The risk factors were evaluated by multivariate logistic regression. A value of $p<0.05$ was considered statistically significant.

The statistical analysis was conducted using statistical computer programs: Statistica 12.0 (StatSoft, Inc.) and Epi Info (WHO).

\section{Results}

\section{Nationwide data}

Complete data were obtained from 12970 adults, including 5939 (45.8\%) men and 7031 (54.2\%) women, with a mean age of $42.8 \pm 17.0$ years. Mean age and sex structure of the analysed group were very similar to those of the general population.

In the analysed group, 2630 respondents were over the age of 60, including 1069 (40.6\%) men and 1561 (59.4\%) women. The elderly represented $20.3 \%$ of the

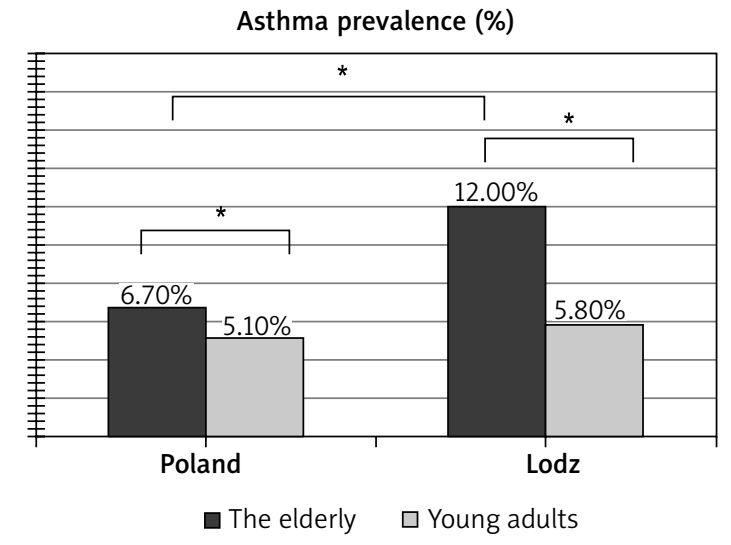

Figure 1. Prevalence of asthma in the general population by age groups - results of the nationwide study and data from the Lodz Province $(p<0.05)$

Table 1. Demographic characteristics and prevalence in adults by sex and age group - nationwide results

\begin{tabular}{|c|c|c|c|c|}
\hline Parameter & $\begin{array}{l}\text { Adult respondents [A] } \\
\text { (aged 16-80) }\end{array}$ & $\begin{array}{l}\text { The elderly [E] } \\
\text { (aged 60-80) }\end{array}$ & $\begin{array}{l}\text { Younger adults }[\mathrm{Y}] \\
\qquad(16-59)\end{array}$ & $\begin{array}{c}P \text {-value } \\
(\mathrm{E} / \mathrm{Y})\end{array}$ \\
\hline Adult respondents, $N(\% \mathrm{~A})$ : & $12970(100 \% A)$ & $2630(20.3 \% A)$ & $10340(79.7 \% A)$ & \\
\hline Females & $7031(54.2 \% \mathrm{~A})$ & 1561 (59.4\%E) & $5470(52.9 \% Y)$ & \\
\hline Males & 5939 (45.8\%A) & 1069 (40.6\%E) & $4870(47.1 \% Y)$ & $<0.01$ \\
\hline $\begin{array}{l}\text { Asthma patients, } N \\
\%(95 \% \mathrm{Cl}):\end{array}$ & $\begin{array}{c}702 \\
5.4(5.0-5.8)\end{array}$ & $\begin{array}{c}176 \\
6.7(5.7-7.7)\end{array}$ & $\begin{array}{c}526 \\
5.1\end{array}$ & 0.001 \\
\hline Females & $\begin{array}{c}411 \\
5.8(5.3-6.4)\end{array}$ & $\begin{array}{c}111 \\
7.1(6.1-8.1)\end{array}$ & $\begin{array}{c}300 \\
5.5(4.9-6.1)\end{array}$ & 0.015 \\
\hline Males & $\begin{array}{c}291 \\
4.9(4.4-5.4)\end{array}$ & $\begin{array}{c}65 \\
6.1(5.2-7.0)\end{array}$ & $\begin{array}{c}226 \\
4.6(4.0-5.2)\end{array}$ & 0.048 \\
\hline$P$-value (F/M) & 0.018 & 0.30 & 0.051 & \\
\hline
\end{tabular}

Data from the Lodz Province. 
Table 2. Demographic characteristics and asthma prevalence in adults by sex and age - results from the Lodz Province

\begin{tabular}{|c|c|c|c|c|}
\hline Parameter & $\begin{array}{l}\text { Adult respondents [A] } \\
\quad \text { (aged 16-80) }\end{array}$ & $\begin{array}{l}\text { The elderly [E] } \\
\text { (aged 60-80) }\end{array}$ & $\begin{array}{l}\text { Younger adults [Y] } \\
\text { (aged 16-59) }\end{array}$ & $\begin{array}{c}P \text {-value } \\
(E / Y)^{*}\end{array}$ \\
\hline Adult respondents, $N(\%)$ & $1057(100 \% A)$ & $249(23.6 \% A)$ & $808(76.4 \% A)$ & \\
\hline Females & $606(57.3 \% A)$ & $162(65.1 \% \mathrm{E})$ & $444(55.0 \% Y)$ & \\
\hline Males & $451(42.7 \% A)$ & 87 (34.9\%E) & $364(45.0 \% Y)$ & 0.005 \\
\hline $\begin{array}{l}\text { Asthma patients, } N \\
\%(95 \% \mathrm{Cl}) \text { : }\end{array}$ & $\begin{array}{c}77 \\
7.3(5.7-8.9)\end{array}$ & $\begin{array}{c}30 \\
12.0(8.0-16.1)\end{array}$ & $\begin{array}{c}47 \\
5.8(4.2-7.4)\end{array}$ & 0.0009 \\
\hline Females & $\begin{array}{c}48 \\
7.9(5.8-10.1) \\
\end{array}$ & $\begin{array}{c}23 \\
14.2(8.8-19.6) \\
\end{array}$ & $\begin{array}{c}25 \\
5.6(3.5-7.8) \\
\end{array}$ & 0.0005 \\
\hline Males & $\begin{array}{c}29 \\
6.4(4.2-8.7) \\
\end{array}$ & $\begin{array}{c}7 \\
8.0(2.2-13.9) \\
\end{array}$ & $\begin{array}{c}22 \\
6.0(3.6-8.5)\end{array}$ & $>0.05$ \\
\hline $\begin{array}{l}\text { Smoking asthma patients, } N \\
\%(95 \% \mathrm{Cl})\end{array}$ & $\begin{array}{c}26 \\
33.8(23.0-44.6) \\
\end{array}$ & $\begin{array}{c}6 \\
20.0(4.8-35.2) \\
\end{array}$ & $\begin{array}{c}20 \\
42(27.9-57.2) \\
\end{array}$ & 0.041 \\
\hline $\begin{array}{l}\text { Current smokers, } N \\
\%(95 \% \mathrm{Cl})\end{array}$ & $\begin{array}{c}12 \\
15.6(7.3-23.9)\end{array}$ & $\begin{array}{c}1 \\
3.3(0.1-10.2)\end{array}$ & $\begin{array}{c}11 \\
23.4(10.8-36.0)\end{array}$ & 0.018 \\
\hline $\begin{array}{l}\text { Former smokers, } N \\
\%(95 \% \mathrm{Cl})\end{array}$ & $\begin{array}{c}14 \\
18(9.4-27.0)\end{array}$ & $\begin{array}{c}5 \\
16.7(2.5-30.8) \\
\end{array}$ & $\begin{array}{c}9 \\
19.1(7.5-30.8)\end{array}$ & $>0.05$ \\
\hline $\begin{array}{l}\text { Asthma patients from SAR, } N \\
\%(95 \% \mathrm{Cl})\end{array}$ & $\begin{array}{c}18 \\
23.4(13.7-33.0)\end{array}$ & $\begin{array}{c}5 \\
16.7(2.5-30.8)\end{array}$ & $\begin{array}{c}13 \\
27.7(14.4-40.9)\end{array}$ & $>0.05$ \\
\hline
\end{tabular}

study group, and a significantly higher percentage of women was found among them compared to the younger group, $59.4 \%$ vs. $52.9 \%$, respectively.

The prevalence of asthma in the entire study population was estimated at 5.4\% (95\% Cl: 5.0-5.8\%). Asthma was significantly more frequently observed in the elderly and the prevalence in this group was $6.7 \%$ (95\% Cl: $5.7-$ 7.7\%) (Figure 1).

Among adults, asthma was significantly more frequent in women (females/males $-5.8 \%$ vs. $4.9 \%, p=$ $0.018)$; this predominance was also visible in the elderly as well as in younger subgroups but due to smaller numbers of subjects, statistical significance was not achieved (Table 1).

In the Lodz Province complete data were obtained from 1057 respondents, including 606 (57.3\%) women and $451(42.7 \%)$ men. The mean age in the study group was $44.58 \pm 17.48$ years. The structure of the analysed group according to age and sex was similar to that of the population in the Lodz Province. This group was slightly older compared to the nationwide sample, and overrepresentation of women in this province was clearly visible even as compared to the national mean ( $p=0.049$ ), which corresponds to the demographic situation in this region (Table 2 ).

In the whole group of respondents, the prevalence of asthma in the Lodz Province was estimated at $7.3 \%$ and the prevalence was significantly higher than the morbidity determined for Poland $(p=0.01)$. Asthma was more frequent among women, but the difference was not statistically significant $(p>0.05)$. However, significantly higher asthma prevalence was found among women in the Lodz Province compared to the national rate $(7.9 \%$ vs. $5.8 \%, p=0.04)$. Among men in the Lodz Province, although asthma prevalence was higher than the national mean, the difference was not statistically significant $(p>0.05)$.

The prevalence of asthma in the elderly in the Lodz Province was $12 \%$ and was significantly higher than in the younger age group (5.8\%, $p=0.0009)$. Among the elderly, asthma was more frequent in women, but the difference between men and women was not statistically significant (14.2\% vs. 8.0\%, $p>0.05)$, while a significant difference was observed between young and elderly females (14.2\% vs. 5.6\%, $p=0.0005)$.

Compared with the national results, the prevalence of asthma in the entire group of the elderly in the Lodz Province was higher (12\% vs. $6.7 \%, p=0.002)$, similarly as in the entire group of adults (Figure 1).

An additional analysis of data from the Lodz Province (Table 3) showed an increased risk of asthma prevalence in patients with seasonal allergic rhinitis (SAR) $(O R=$ $8.56,95 \% \mathrm{Cl}: 2.32-31.63, p=0.001)$. A similar relationship was observed in the younger age group, although of lower strength $(\mathrm{OR}=2.82,95 \% \mathrm{Cl}: 1.43-5.53, p=0.003)$. In the case of people living in the city centre, there was also higher asthma prevalence than in suburban and rural areas, but this difference in the elderly group did not reach statistical significance $(O R=1.59,95 \% \mathrm{Cl}: 0.72-3.50$, $p>0.05)$ due to the small size of the sample; however, it was significant in the younger age group $(O R=5.48$, 95\% Cl: 2.88-10.43, $p=0.001$ ).

The multivariate analysis confirmed that significant risk factors for asthma prevalence among the inhabitants 
Table 3. Risk factors of asthma by age groups

\begin{tabular}{|c|c|c|c|c|c|c|}
\hline \multirow{2}{*}{$\begin{array}{l}\text { Age groups } \\
>60 \text { years of age }\end{array}$} & \multicolumn{2}{|c|}{ Risk factors } & \multirow{2}{*}{$\begin{array}{c}\text { Asthma (+) } \\
n(\%) \\
19(14.3)\end{array}$} & \multirow{2}{*}{$\begin{array}{c}\text { Asthma (-) } \\
n(\%) \\
114(85.7)\end{array}$} & \multirow{2}{*}{$\begin{array}{c}\text { OR }(95 \% \mathrm{Cl}) \\
1.59(0.72-3.50)\end{array}$} & \multirow{2}{*}{$\begin{array}{l}P \text {-value } \\
>0.05\end{array}$} \\
\hline & Place of residence & City centre & & & & \\
\hline & & Outside the centre & $11(9.5)$ & $105(90.5)$ & & \\
\hline & Asthma and SAR & SAR $(+)$ & $5(50)$ & $5(50)$ & $8.56(2.32-31.63)$ & 0.001 \\
\hline & & SAR $(-)$ & $25(10.5)$ & $214(89.5)$ & & \\
\hline \multirow[t]{4}{*}{$16-60$ years of age } & Place of residence & City centre & $33(12.6)$ & $229(87.4)$ & $5.48(2.88-10.43)$ & 0.001 \\
\hline & & Outside the centre & $14(2.6)$ & $532(97.4)$ & & \\
\hline & Asthma and SAR & SAR $(+)$ & $13(12.5)$ & $91(87.5)$ & $2.82(1.43-5.53)$ & 0.003 \\
\hline & & SAR (-) & $34(4.8)$ & $670(95.2)$ & & \\
\hline
\end{tabular}

Table 4. Underdiagnosis of asthma in the Lodz population - prevalence of the phenomenon in the general population

\begin{tabular}{lcccc}
\hline Parameter & $\begin{array}{c}\text { Adult respondents }[\mathrm{A}] \\
(\mathbf{1 6 - 8 0} \text { years })\end{array}$ & $\begin{array}{c}\text { The elderly [E] } \\
(60-80 \text { years })\end{array}$ & $\begin{array}{c}\text { Younger adults [Y] } \\
(16-59 \text { years })\end{array}$ & $\begin{array}{c}\text { P-value } \\
(\mathrm{E} / \mathrm{Y})\end{array}$ \\
\hline Earlier diagnosed subjects, $N(\%)^{*}$ & $40(3.8)$ & $16(6.4)$ & $24(3.0)$ & 0.062 \\
\hline $\begin{array}{l}\text { Lack of earlier asthma diagnosis } \\
\text { in patients, } N(\%)^{*}\end{array}$ & $39(3.7)$ & $15(6.0)$ & $24(3.0)$ & 0.025 \\
\hline False positive diagnosis, $N(\%)^{*}$ & $2(0.5)$ & $1(0.4)$ & $1(0.1)$ & 0.378 \\
\hline
\end{tabular}

*Prevalence in the general population.

of the Lodz Province were: age over 60 years, residence in the city centre and the occurrence of seasonal allergic rhinitis (Figure 2).

The study also analysed the conformance of asthma diagnoses established by an expert during an epidemiological trial and verified in the centre on the basis of additional studies to the diagnoses previously made by primary care physicians and specialists. In the elderly group, in almost $50 \%$ of asthma patients, the disease had not been correctly diagnosed although patients had reported clinical symptoms. A similar scale of the phenomenon of underdiagnosing asthma was observed in the younger age group (Table 4). Only a small percentage of patients had had a recognized disease, though asthma was not confirmed in the epidemiological trial. Tobacco smoking increased the likelihood of underdiagnosis four times $(\mathrm{OR}=3.983)$, but statistical significance was not reached for this factor $(p=0.072)$.

\section{Discussion}

Data concerning the prevalence of asthma in Poland are based on two nationwide epidemiological studies. The first one, the Polish Multicentre Study in Epidemiology of Allergic Diseases (PMSEAD), was conducted in 1998-1999 [6], and the second one, the Epidemiology of Allergic Disorders in Poland (ECAP) [7], between 2006 and 2008. The prevalence of asthma in the Polish general population of adults was estimated to be $5.4 \%$ in the PMSEAD study and $9.4 \%$ in the ECAP study. Only the first study includes the group of the elderly and enables

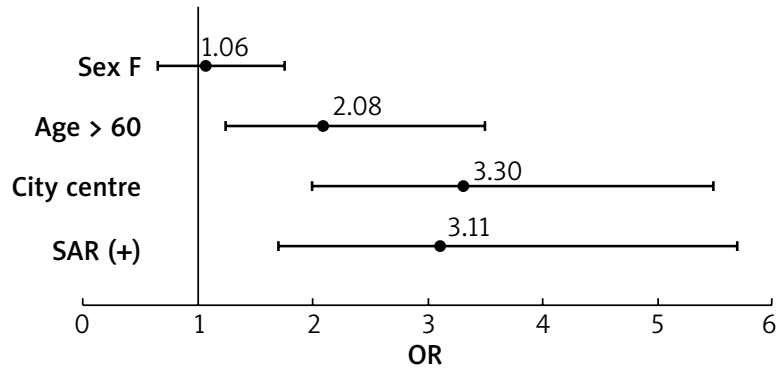

Figure 2. Risk factors of asthma in the Lodz population according to the multivariate analysis

evaluation of health problems of asthma patients in this age group. For the purpose of the statistical analysis in the present research, the age of 60 years at the time of conducting the survey was regarded as the threshold of old age, according to the WHO criteria.

The prevalence of asthma in the elderly in Poland was estimated at $6.7 \%$ and was significantly higher than among younger adults (5.1\%). International data indicate that the prevalence for asthma among old people ranges from $6.5 \%$ to $17 \%$, which shows that the outcomes achieved in the PMSEAD study fall within the international trends, though their values reach lower limits of intervals. However, in Poland, a general tendency towards higher asthma incidence rates has been observed; therefore a higher incidence is also expected in this age group with time.

The prevalence of asthma in the Lodz subgroup of adults was higher than the nationwide mean (7.3\% vs. 
5.4\%). Higher asthma prevalence in adults was recorded in Krakow (7.6\%) [6]. Also, in the Lodz Province, higher asthma prevalence was observed in the elderly than in residents of younger age ( $12 \%$ vs. $5.8 \%$ ).

The higher prevalence of asthma among older adults as compared to younger subjects can be explained by the cumulative incidence of this disease. Asthma is still considered to be an incurable entity, and although its morbidity is the highest during childhood, it can be diag nosed at any age. Besides genetic determinants, environmental factors (chemical and biological atmospheric pollution, exposure to allergens, infections, obesity), whose total exposure increases with age, are also significant [9]. Analysis of data from the PMSEAD study shows that asthma is more common among people living in big cities [8]. A significant contribution to this phenomenon is attributed to the exposure to vehicle exhaust which accumulates in city centres [8]. Another postulated factor is the changing microclimate of cities (heat islands, less air humidity) and urban lifestyle (e.g. reduced physical activity, consumption of highly processed food, administration of numerous medications, reduced exposure to saprophytic bacteria) [10].

The present analysis also demonstrates higher asthma prevalence among the elderly in the city centre than in suburban areas, and although the risk analysis failed to achieve statistical significance due to the small size of the groups, this relationship is distinct in the younger age group, where the number of subjects is greater.

Environmental exposures overlap the aging processes. Thus, changes in the immune system (reduction in the number of immature T lymphocytes, reduction in Th1 and Tcs activity, decreased IL-2 production in response to antigen, and overactivation of Th17 lymphocytes) lead to increased incidence of viral and bacterial infections, simultaneously shifting the inflammatory response towards Th2-dependent [11]. In the study of Kołomecka et al., in which skin prick tests with inhaled allergens were performed, allergies in the asthmatic elderly (over 60 years of age) were determined in $57 \%$ of subjects with early-onset asthma phenotype and $40 \%$ with late-onset phenotype [12].

Asthma in the elderly has a more severe course as compared to younger adult patients. Statistical analyses show that the requirement for rescue medications in this group is twice as high as in younger patients; the frequency of hospitalization is three times higher [4] and the mortality rate 1.5 times higher [13].

Meanwhile, many problems are encountered while establishing the diagnosis of asthma in the elderly. During this period of life, cardiovascular and respiratory diseases often present with similar symptoms as asthma. The elderly patients from this group more frequently have technical problems with the correct performance of the spirometry procedure. Therefore, asthma in the elderly too often remains unrecognized. In our analysis,
$50 \%$ of patients with asthma had had no proper diagnosis established, despite reporting typical symptoms of the disease. In the study by Enright et al. carried out in patients aged 65 years or older, $4 \%$ of them reported having diagnosed asthma and another $4 \%$ reported typical symptoms [14]. Similarly, in the study by Bellia et al., only $53.1 \%$ of asthmatics (mean age: 73 years) had a prior diagnosis, $19.5 \%$ had a wrong diagnosis of chronic obstructive pulmonary disease (COPD)/pulmonary emphysema, and $27.3 \%$ did not have any recognized disease of the respiratory system [15]. A lack of proper diagnosis and treatment is associated with a higher risk of death from asthma.

According to our analysis, co-occurrence of symptoms of seasonal allergic rhinitis in the elderly increases the probability of asthma development. Also in the study of Bellia et al., the prevalence of hay fever increased the likelihood of diagnosing asthma [15]. Allergic rhinitis is a known risk factor for the development of asthma, often preceding its occurrence. This results from the common pathomechanisms, and the difference in symptoms is caused by the different construction of the airways. The prevalence of seasonal rhinitis among the elderly was estimated at 5.3\% in the PMSEAD study [16].

\section{Conclusions}

In Poland, bronchial asthma is a frequent disease in the elderly which is often under-diagnosed. Untreated asthma is a cause of serious health- and life-threatening exacerbations, frequent visits to a physician, emergency ambulance interventions, hospital admissions and longterm hospitalization. Primary care practitioners should be aware of the high prevalence of this disease among elderly persons, and be particularly alert of the new cases whose symptoms may be misinterpreted as signs of circulatory failure or COPD. Physicians should consult specialists if they have any doubts concerning diagnosis of asthma in this group of patients.

\section{Acknowledgments}

The study has been funded by grant No KBN 4P05B10213 awarded by the Research Committee and by grant G-31/98 awarded by the City Council of Lodz.

\section{Conflict of interest}

The authors declare no conflict of interest.

\section{References}

1. http://www.who.int/mediacentre/factsheets/fs357/en/Update January 2018.

2. Rocznik Demograficzny Główny Urząd Statystyczny, Warsaw 2016. Available at: http://www.stat.gov.pl

3. Majcha Z, Szczepaniak W. Epidemiologia astmy oskrzelowej w różnych grupach wiekowych. In: Astma oskrzelowa 
w wieku podeszłym. Panaszek B (ed.). Termedia, Poznan 2011; 17-22.

4. Panaszek B. Wprowadzenie. In: Astma oskrzelowa w wieku podeszłym. Panaszek B (ed.). Termedia, Poznan 2011; 7-15.

5. Machaj Z, Szczepaniak W. Cechy populacyjne wyróżniające grupę osób chorych na astmę wieku podeszłego. In: Astma oskrzelowa w wieku podesztym. Panaszek B (ed.). Termedia, Poznan 2011; 23-24

6. Liebhart J, Małolepszy J, Wojtyniak B, et al.; members of the Polish Multicentre Study of Epidemiology of Allergic Diseases (PMSEAD). Prevalence and risk factors for asthma in Poland: results from the PMSEAD Study. I Investing Allergol Clin Immunol 2007; 17: 367-74.

7. Samoliński B, Sybilski AJ, Raciborski F, et al. Występowanie astmy oskrzelowej u dzieci, młodzieży i młodych dorosłych w Polsce w świetle badania ECAP. Astma Alergia Immunologia 2009; 14: 27-34.

8. Kuprys-Lipinska I, Elgalal A, Kuna P. Urban-rural differences in the prevalence of atopic diseases in the general population in Lodz Province (Poland). Post Dermatol Alergol 2009; 26: 249-56.

9. Kuprys-Lipinska I, Kuna P. Urban Green Areas on the Epidemiology of Allergic Diseases and Asthma. In: Urban Ecohydrology. Research and Implementation in Lodz - demonstration City of SWITCH. Final report of the EU Project SWITCH (GOCE 018530). Zalewski M, Wagner I (eds.). University of Lodz, Lodz 2011; 419-34.

10. Kuprys-Lipinska I, Kuna P, Wagner I. Woda w przestrzeni miejskiej a zdrowie mieszkańców. In: Woda w mieście. Bergier T, Kronenberg J, Wagner I (eds). Seria wyd. „Zrównoważony rozwój - zastosowania", Wydawca Fundacja Sendzimira, Krakow 2014.

11. Kopeć A, Fal AM. Układ immunologiczny w podeszłym wieku. In: Astma oskrzelowa w wieku podesztym. Panaszek B (ed.). Termedia, Poznan 2011; 25-33.

12. Kołomecka M, Bocheńska-Marciniak M, Kuna P, Górski P. Udział atopii oraz wartość diagnostyczna prick-testów w astmie oskrzelowej u osób po 60 roku życia. Alergia Astma Immunologia 2000; 5 (suppl.): 292.

13. Bellia V, Pedone C, Catalano F, et al. Asthma in the elderly: mortality rate and associated risk factors for mortality. Chest 2007; 132: 1175-82.

14. Enright PL, McClelland RL, Newman AB, Gottlieb DJ, Lebowitz MD. Underdiagnosis and undertreatment of asthma in the elderly. Cardiovascular Health Study Research Group. Chest 1999; 116: 603-13.

15. Bellia V, Battaglia S, Catalano F, et al. Aging and disability affect misdiagnosis of COPD in elderly asthmatics: the SARA study. Chest 2003; 123: 1066-72.

16. Kuprys-Lipinska I, Tworek D, Liebhart J, Kuna P. Epidemiology of seasonal allergic rhinitis in the elderly in general population in Poland. Allergy 2008; 63 (Suppl. 88): 417. XXVII Congress of EAACl Abstract Book, Barcelona 7-11 June 2008. 